\title{
Indirect Solar Drier with Electric Back up System for Quality Hill Products
}

\author{
Rajeev Kumar Aggarwal ${ }^{1}$, Madan Mohan Sharma ${ }^{2}$, Ashwani Kumar Sharma ${ }^{2}$ \\ ${ }^{1}$ Department of Environmental Science, Dr Y S Parmar University of Horticulture \& Forestry, Nauni (Solan), India; ${ }^{2}$ Department of \\ Basic Sciences, Dr Y S Parmar University of Horticulture \& Forestry, Nauni (Solan), India. \\ Email: rajeev1792@rediffmail.com
}

Received October $25^{\text {th }}, 2010$; revised November $23^{\text {rd }}, 2010$; accepted December $3^{\text {rd }}, 2010$.

\begin{abstract}
An indirect solar drier of $25 \mathrm{~kg}$ capacity has been developed fitted with solar cell for running the fan. The bulbs are provided in the solar collector for air heating during clouds and evening \& morning for faster drying reducing drying time. Various hill crops (Punica granatum L, Ginger, Turmeric and Red chili) have been dried in open sun, oven and solar drier for quality/caparison. The dried products were tested in the post harvest technology laboratory for value addition. The market value of dried products has also been compared.
\end{abstract}

Keywords: Solar Drier, Drying, Hill Crops, Quality, Income Generation

\section{Introduction}

The Himachal Pradesh is a hilly state known as fruit bowl of India. Large quantities of fruits and vegetables are damaged due to perishable nature/bad weather or lack of transportation facilities resulting in loss to the farmers. About 20\% tomato, $10 \%$ ginger, $10 \%$ mushroom, $30 \%$ amla (Emblica officinalis) and 5\% apple are generally damages/waste during a year. People in the state dries fruits apple, peach, palm nut, and vegetables chilly, turmeric, ginger and pomegranate in open sun resulting poor quality of the dried product due to dust/fungus infection, insects, sudden rains, bacteria and loss due to wetting by rainsqualls wild animals and monkeys etc.. The part of perishable crops like tomatoes and pomegranate harvested during rainy season are wasted due to bad weather. This gives low return to the farmers. The open sun drying requires more time and labour to carry products from inside to outside during bad weather. Solar drying of fruits and vegetables can reduce the losses and improve the quality of products for better price in the market. Several types of driers are available in the country but these are not popular in rural areas due to high costs, technical know how, or lack of skill to use these driers [1]. An indirect solar powered drier has been developed for the drying of fruits, vegetables, seeds and medicinal plants. This drier reduces the drying time considerably as it provides heat during night through bulbs. The quality of the products improves for better market values. The pay back period of the drier is less because the drier will be used throughout the year. The major portion of the initial expenditure on fabrication of drier is on wood, which is easily available with the farmers. Thus, the total cost of the drier will be reduced which can be recovered in shorter span. The hill products dried for commercial use are presented in Table 1.

Table 1. Calendaring of hill crops dried for commercial use.

\begin{tabular}{|c|c|c|c|}
\hline \multirow{2}{*}{$\begin{array}{c}\text { Month of } \\
\text { harvesting }\end{array}$} & \multicolumn{3}{|c|}{ Crop to be dried } \\
\hline & Fruits & Vegetables/Seeds & Medicinal plants \\
\hline January & & $\begin{array}{l}\text { Turmeric, Methi, } \\
\text { Sarson, }\end{array}$ & \\
\hline February & Amla & Brass, Guchhi & \\
\hline March & & & Bnaksha, \\
\hline April & & Peas, Garlic & \\
\hline $\begin{array}{l}\text { May } \\
\text { June }\end{array}$ & Mango & & \\
\hline July & Apples, & $\begin{array}{l}\text { Beans, Potato, } \\
\text { Pumpkin }\end{array}$ & \\
\hline $\begin{array}{c}\text { August } \\
\text { September }\end{array}$ & $\begin{array}{l}\text { Walnut, } \\
\text { Apricot, } \\
\text { Almond }\end{array}$ & $\begin{array}{c}\text { Anardana, } \\
\text { Red Chilly, Maize }\end{array}$ & Kala Jeera, \\
\hline October & & Ginger & Brahme, Kesar \\
\hline November & & & \\
\hline December & & & $\begin{array}{l}\text { Mulhathi, Tulsi, } \\
\text { Sarpgndha, Ashwa- } \\
\text { gandha, Jatamansi }\end{array}$ \\
\hline
\end{tabular}


Pomegranate has great economic importance because of its high acetic nature. Nearly 1000 tones of dried anardana extracted from wild pomegranate fruits costs about $\$ 3.0$ billions. Wild pomegranate is widely found in dried and sub-marginal land of mild hill region of outer Himalayas at an altitude of $400 \mathrm{~m}$ to $1,800 \mathrm{~m}$ above mean sea level. In India it grows in vast track of the hill slopes of Jammu \& Kashmir, Himachal Pradesh and Utranchal. In Himachal Pradesh it is found in Solan and Sirmour districts in abundance. The size of fresh pomegranate varies from $5.31 \mathrm{~cm}$ to $7.53 \mathrm{~cm}$ and diameter varies from $4.35 \mathrm{~cm}$ to $6.50 \mathrm{~cm}$. The weight ranges between $59.77 \mathrm{gm}$ to $101.0 \mathrm{gm}$. The average weight of 100 arils is $12.65 \mathrm{gm}$ and its colour is blood red-light pink.

Ginger is one of the important spice crops that are preferred for its therapeutic values. An herbaceous perennial plant, belonging to family Zingiberaceae is believed to be native of south East Asia. It is propagated through rhizomes, leafy stem $30-90 \mathrm{~cm}$ in height. It is widely used in food beverages, confectioneries and medicine. Total production in the world is 1004546 metric tones and total world area under cultivation is 33826 hectares. The average productivity of the world is 2956 $\mathrm{kg} /$ hectare. Major ginger producing countries in the world are India, Nigeria, China, Thailand, Indonesia, Bangladesh, Philippines and Korea. Nigeria ranks first with respect to area under ginger covering about $56.23 \%$ of world total area under ginger followed by India (23.60\%), China (4.47\%), Indonesia (3.37\%) and Bangladesh $(2.32 \%)$ India ranks first with respect to ginger production contributing about $32.75 \%$ of total world's ginger product followed by china $(21.41 \%)$, Nigeria $(12.54 \%)$ and Bangladesh (10.80\%). India is the largest producer of dry ginger. The total production of ginger in India is 305900 tones in an area of 85100 hectare with an average production of ginger 3.60 metric tones per hectare. In India, Kerla is the highest producer of ginger contributing almost $23.08 \%$ of country's total production followed by $19.57 \%$ in Meghalaya. Major ginger producing area in country is Karnataka Tamil Nadu, west Bengal, Himachal Pradesh, UP, Orrisa Gujart, Maharastra, Rajasthan and North-Eastern states [3]. In Himachal Pradesh, ginger is one of the important cash crops of mid and lower hills covering an area of 3695 hectares and total production is 37,000 tones. In Himachal Pradesh, this crop is mainly grown in Sirmaur, Solan, Hamirpur, Bilaspur, Mandi and Shimla districts.

\section{Methodology}

The drier has been developed under the project funded by the Ministry of Science and Technology, Government of India. A survey was conducted to identifying the drying techniques of the farmers and to identify the commercial crop which are being dried. On the basis of this survey an indirect solar drier has been developed. The design parameters of the drier have been presented in Section 1). The results and discussion is presented in Section 2). The economics of drying has been discussed in Section 3).

\section{1) Design parameters of the drier}

The solar drier of $25 \mathrm{~kg}$ capacity has two components. One a solar collector constructed with water proof board fitted with $4 \mathrm{~mm}$ glass at an angle of $30^{\circ}$ (the latitude of the place) for maximum transmission of solar radiation (drawing is enclosed) [2]. Solar collector with a glass area of 2.4 square meter and volume is $0.693 \mathrm{~m}^{3}$. The solar collector base has black painted plywood to absorbed solar radiation insulated with saw dust. The drying chamber with dimension of $1.1 \mathrm{~m} * 0.7 \mathrm{~m} * 1.0 \mathrm{~m}$ has three removable trays. Each tray with size of $1.02 \mathrm{~m}$ $* 0.7 \mathrm{~m} * 0.05 \mathrm{~m}$ is made of iron square mesh in wooden border. Front side of drying chamber is covered by glass having thickness of $6 \mathrm{~mm}$. The eight bulbs of $100 \mathrm{~W}$ each are provided in the solar collector for heating during rains and after sunset to reduce the drying time. The holes are provided at the bottom (south orientation) in solar collector. A dc fan is provided at top of the drying chamber (north orientation) for air circulation. A solar battery has been attached with the drying chamber to run the fan. A schematic view and camera photograph of solar drier are presented in Figure 1 and Figure 2 respectively.

\section{2) Result and discussion}

The three samples (solar dried, open sun dried, oven dried) of each dried products were given for value addition test to the Department of Post Harvest Technology, Dr Y S Parmar University of Horticulture \& Forestry, Nauni (Solan) India. No preliminary chemical treatment was given to the products to be dried. Drying results of pomegranate which are presented in Table 2 reveal that reducing sugar was found maximum $(21.70 \%)$ in the arils dried in indirect solar drier while minimum (20.25\%) was in open sun. The total sugars were found maximum $(24.18 \%)$ in arils dried in indirect solar drier and minimum $(22.60 \%)$ in open sun. The maximum titratable acidity $(13.71 \%)$ in the arils dried in oven, whereas minimum titratable acidity of $12.40 \%$ was observed in the arils dried in open sun. The electric oven was used for drying at constant temperature. Data on the effect of drying modes on the ascorbic acid content show that indirect solar dried arils had maximum $(12.09 \mathrm{mg} / 100 \mathrm{~g})$ ascorbic acid, whereas open sun dried arils had minimum (7.85 $\mathrm{mg} / 100 \mathrm{~g})$ ascorbic acid. Data pertaining to the effect of drying modes on the visual colour of arils indicate different colour shades of pink to light brownish. Arils dried in indirect solar drier had pink colour, which was most attractive as compared to the other two modes. Brownish pink colour of arils was observed in oven 


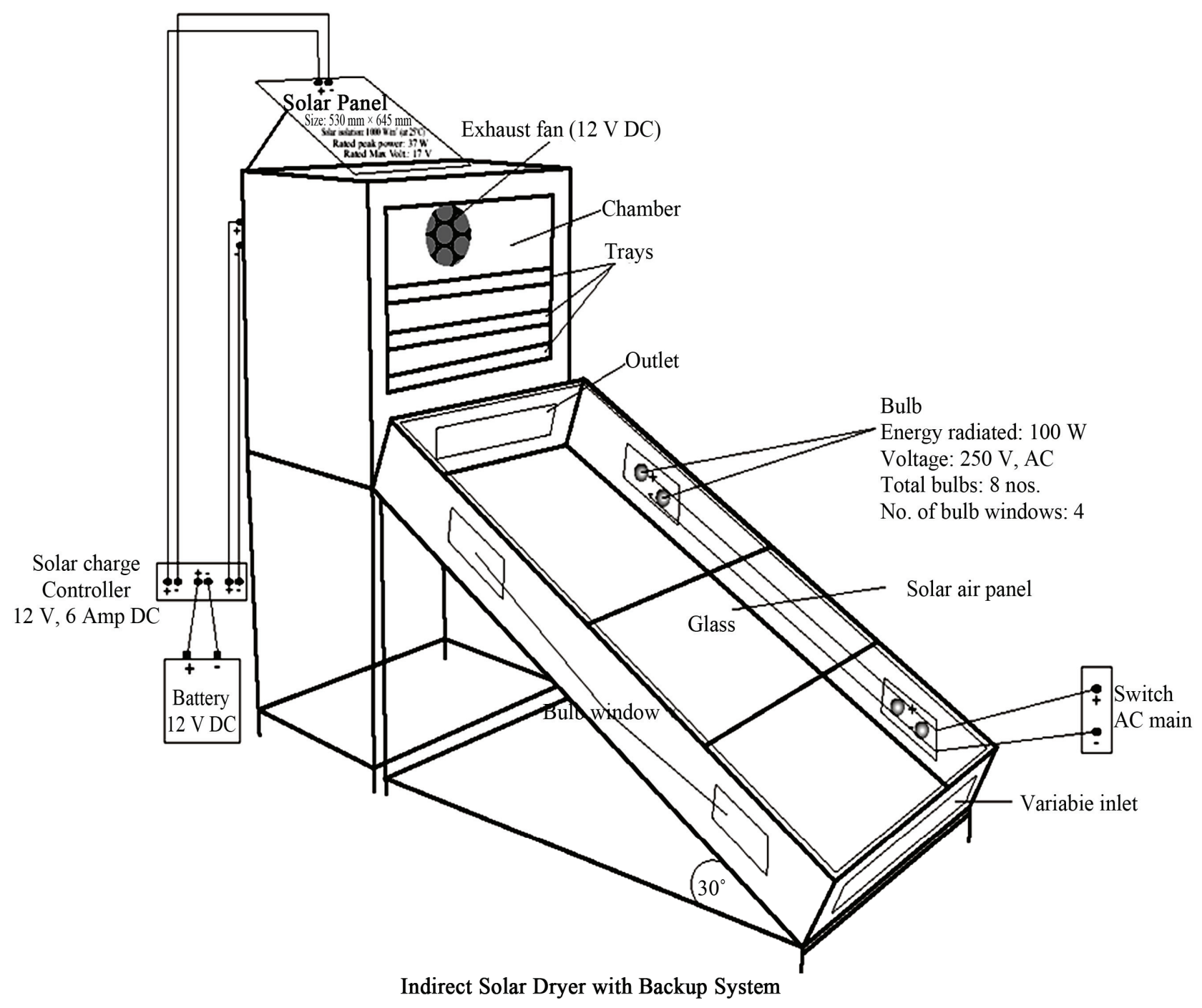

Figure 1. Design of indirect solar drier.

samples, whereas, least attractive light brown colour was observed in the arils dried in open sun. Minimum (7.58\%) moisture content was recorded in the arils dried in oven, whereas maximum (11.32\%) moisture content observed in arils dried in open sun. The time taken to dry the pomegranate is 21 hours in solar drier. The eight bulbs were remained on during sunset which resulted in continuous heating. The temperature variation with time during the drying of pomegranate has been presented in Figure 3 and moisture content variation with time in case of pomegranate has been presented in Figure 4.

Data pertaining to the effect of drying modes on the visual colour of zinger indicate different shades of original yellow to dull. Zinger dried in indirect solar drier had original yellow colour, which was most attractive as compared to the other two modes. Greenish yellow colour observed in the sun sample, whereas, as least attrac- tive dull colour observed in the oven sample. Minimum $(5.88 \%)$ moisture was recorded in the zinger dried in oven, while maximum $(9.54 \%)$ moisture observed in zinger dried in sun. The moisture content $(9.3 \%)$ between other two modes was observed in indirect solar drier. Maximum (5.25\%) oleoresin oil on dry weight basis was recorded in the indirect solar drier where as minimum $(4.79 \%)$ oleoresin oil was recorded in open sun sample. This shows that in indirect solar drier the oil erosion was less as compared to other modes. The drying time of ginger is 20 days in solar drier. The eight bulbs were remained on during sunset which resulted in continuous heating. The moisture content could not be recorded due to instrument failure although the drying was continued. The temperature variation and moisture content variation with time in case of ginger have been presented in Figure 5 and Figure 6 respectively. 


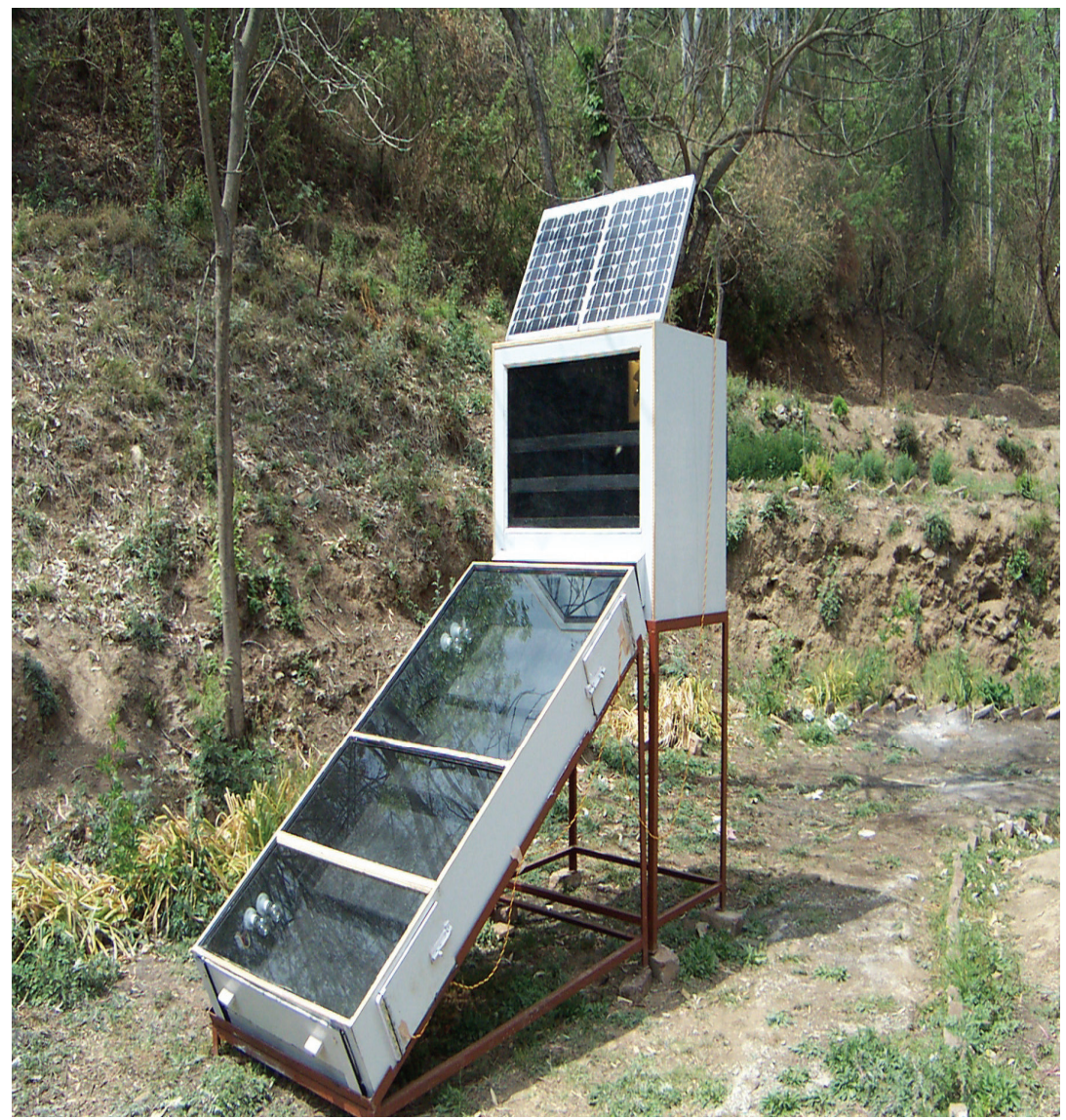

Figure 2. Indirect solar drier.

Table 2. Value addition test results of various dried products.

\begin{tabular}{|c|c|c|c|}
\hline \multirow{2}{*}{ Characteristics } & \multicolumn{3}{|c|}{ Anardana } \\
\hline & Open sun & Oven & Solar drier \\
\hline Reducing sugar (\%) & 20.25 & 21.20 & 21.70 \\
\hline Total Sugar (\%) & 22.60 & 23.49 & 24.18 \\
\hline Titratable acidity (\%) & 12.40 & 13.71 & 13.09 \\
\hline Ascorbic acid (mg/100 gm) & 7.85 & 10.39 & 12.09 \\
\hline Moisture content (\%) & 11.32 & 7.58 & 9.02 \\
\hline Colour & Light brownish & Brownish pink & Pink \\
\hline \multicolumn{4}{|c|}{ Ginger } \\
\hline Colour & Greenish yellow & Dull & Original yellow \\
\hline Oleoresin $(\%)$ on dry wet basis & 4.79 & 4.98 & 5.25 \\
\hline Moisture content (\%) & 9.54 & 5.88 & 9.3 \\
\hline \multicolumn{4}{|c|}{ Red Chili } \\
\hline Colour & Light red & Blackish dark red & Redish pink \\
\hline Moisture content (\%) & 11.94 & 6.38 & 7.34 \\
\hline \multicolumn{4}{|c|}{ Turmeric } \\
\hline Colour & Light redish yellow & Blackish yellow & Dark redish yellow \\
\hline Moisture content $(\%)$ & 11.37 & 7.59 & 9.23 \\
\hline
\end{tabular}




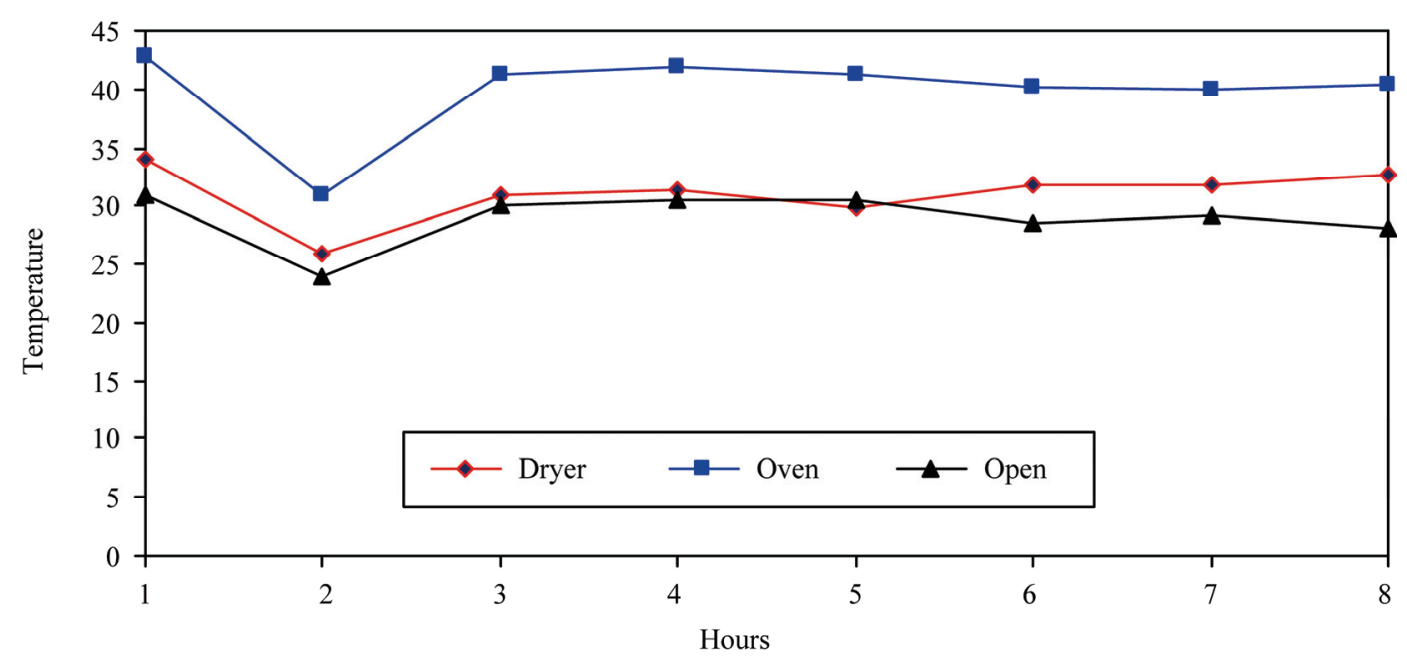

Figure 3. Temperature variation with days in three modes of drying of pomegranate.

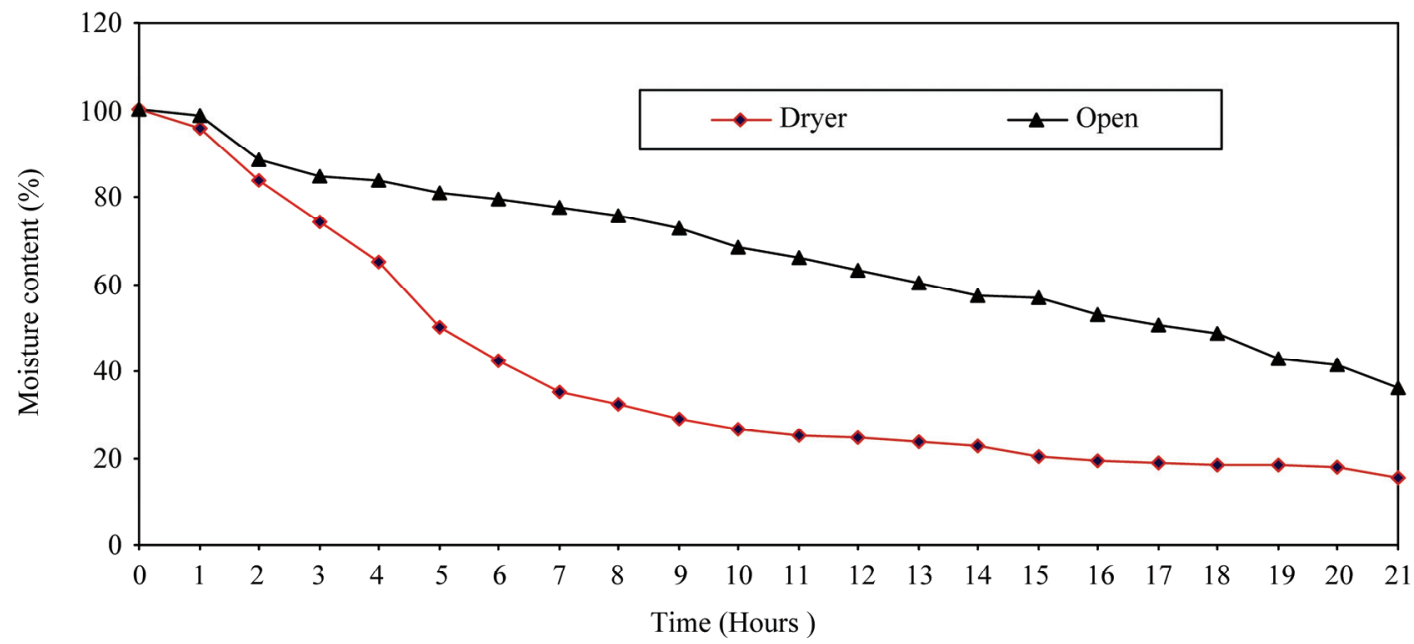

Figure 4. Moisture content variation during month of November and December in case of pomegranate.

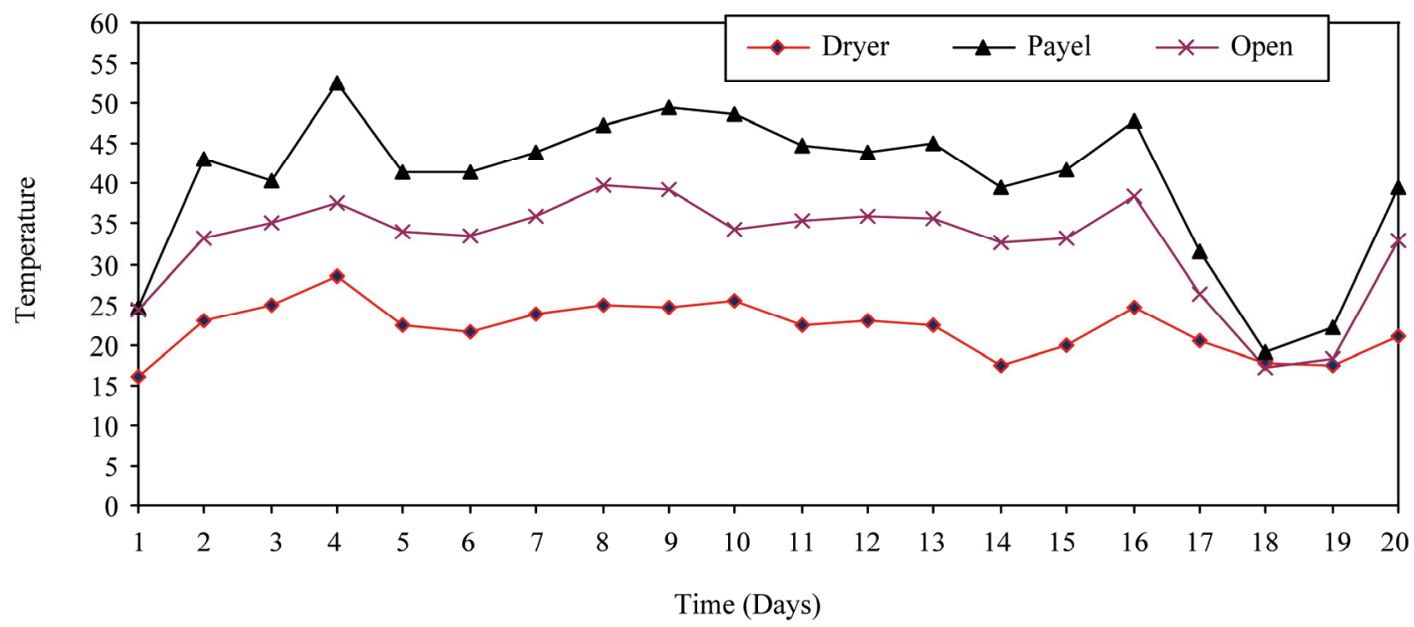

Figure 5. Temperature variation during month of November and December in case of ginger. 


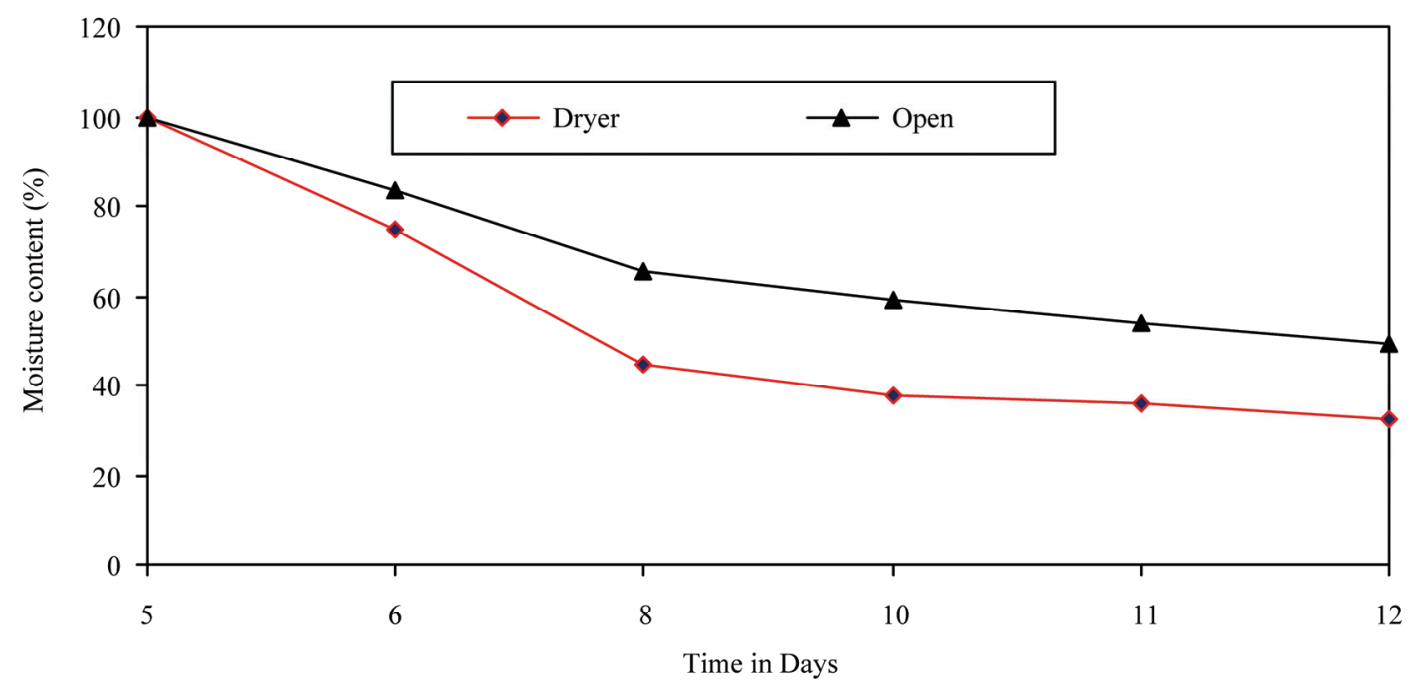

Figure 6. Moisture content variation during month of November and December in case of ginger.

Table 3. The cost per unit capacity of different products.

\begin{tabular}{lcccc}
\hline \multirow{1}{*}{ Item } & \multicolumn{3}{c}{ Product } \\
\cline { 2 - 5 } & Pomegranate & Turmeric & Ginger & Chilli \\
\hline Electricity charges (Rs.) & 25.92 & 16.2 & 87.48 & 12.96 \\
Maintenance charges (Rs.) & 100 & 100 & 100 & 100 \\
Labour charges (Rs.) & & & & \\
Loading & 6.9 & 6.9 & 6.9 & 6.9 \\
Operating cost & 3.68 & 14.0 & 75.6 & 4.2 \\
Depreciation charges (Rs.) & 22.4 & $\mathbf{5 . 5 7}$ & $\mathbf{1 1 . 2 9}$ & $\mathbf{5 . 0 4}$ \\
Cost per unit capacity & $\mathbf{6 . 3 6}$ & & &
\end{tabular}

Table 4. Rates (Rs./kg) of dried products in the local market.

\begin{tabular}{cccc}
\hline Product & Open sun dried & Oven dried & Solar drier dried \\
\hline Anardana & 170 & 170 & 190 \\
Ginger & 190 & 195 & 210 \\
Red chilly & 115 & 105 & 130 \\
\hline
\end{tabular}

Data pertaining to the effect of drying modes on the visual colour chilli indicate different colour shades of light red to reddish pink. The colour of chilli dried in indirect solar drier was most attractive than the other two, modes. Minimum (7.34\%) moisture content recorded in the chilli dried in oven whereas maximum (11.94) moisture content recorded in the open sun sample. Moisture content $(6.38 \%)$ was recorded in the indirect solar drier sample.

Data pertaining to the effect of drying modes on the visual colour turmeric indicate different colour shades of reddish dark yellow to light reddish yellow. Colour of turmeric dried in indirect solar drier was most attractive than the other two, modes. Minimum (7.59\%) moisture content recorded in the turmeric dried in oven whereas maximum $(11.37 \%)$ moisture content recorded in the open sun sample. Moisture content $(9.23 \%)$ was recorded in the indirect solar drier sample.

\section{3) Economics of drying}

The cost per unit capacity of various dried products have been calculated taking into account the cost of drier, labour charges, maintenance charges, electricity charges and depreciation charges [4]. The cost of dried product has been found to be in the range of Rs.5 to Rs.6 per kg. 
The details are presented in Table 3.

\section{Market Value}

The dried products were taken to the local market for assessing the rates of these products. It was found that rates of solar dried products are higher than the dried products by other methods. The rates are presented in Table 4.

\section{REFERENCES}

[1] A. Rajeev, "Design, Fabrication, Installation and Field Evaluation of $1000 \mathrm{~kg}$ Capacity Solar Drier for Chilgoza
Seed Extraction," RERIC International Energy Journal, Vol. 20, No. 2, 1998, pp. 67-76.

[2] C. B. Joshi, M. B. Gewali and R. C. Bhandari, "Performance of Solar Drying Systems: A Case Study of Nepal," IE(I) Journal, Vol. 85, No. 2, 2004, pp. 53-57.

[3] E. Azad, "Design and Experimental Study of Solar Agricultural Dryer for Rural Area," Livestock Research for Rural Development, Vol. 20, No. 9, 2008.

[4] A. Sreekumar, P. E. Manikantan and K. P. Vijayakumar, "Performance of Indirect Solar Cabinet Dryer," Energy Conversion and Management, Vol. 49, No. 6, June 2008, pp. 1388-1395. 